\title{
The Space of Identity and the Identity of Space in The City Wit by Richard Brome
}

\author{
Cristina Paravano \\ Milan State University
}

\begin{abstract}
My paper examines The City Wit (1629-1632), a city comedy by Richard Brome revolving around the unscrupulous trade world, where all the characters aim at social recognition, even trampling on feelings and moral values. My objective is to investigate the play as one of the earlier examples of strategic use of space in Brome's dramatic production. Firstly, I will consider the function of space in relation to the identity of the single characters. Secondly, I will show how space can be manipulated for the refashioning of a new identity, as in the case of Jeremy, a male servant disguised as a widow, who builds up a fictitious Cornish identity. Finally, I will analyze the geography of the play focusing in particular on the scene set in the Presence Chamber of Whitehall.
\end{abstract}

KEY WORDS: space, identity, fashioning, geography, gender.

From the very beginning of his career, Richard Brome proves his ability as a playwright with The City Wit (1629-1632), an entertaining and politically audacious city comedy, and an early example of "accomplished and theatrically intelligent writing" (Schafer 2010:intro §1). Here I propose to discuss The City Wit as one of Brome's earlier attempts at a strategic use of space. On the one hand, I investigate the geography of the play considering the places evoked through specific references and illustrating their different functions in relation to the identity of the characters: when they reflect the self of a single personage or when they contribute to the re-fashioning of a new identity, as in the case of Jeremy, a male servant disguised as a widow, who builds up a fictitious Cornish

Gederi 21 (2011): 71-9o

https://doi.org/10.34136/sederi.2011.4 
identity to deceive his opponents. On the other hand, I analyze how Brome deals with the royal politics and the dishonesty institutionalized within the system by staging the Presence Chamber in absence of the monarch. The City Wit stands out as an unicum, since Act III, scene 4 is explicitly set in the Presence Chamber inside Whitehall, where nobody before Brome had dared to set a play, even for the celebration of a sovereign.

As its title indicates, ${ }^{1}$ the play appears to focus both on the concept of wit and on city life: it revolves around the world of trade, a microcosm where all the characters attempt to establish business relations in order to reach the status of "city wit." ${ }^{2}$ According to the Oxford English Dictionary, the word "wit" ${ }^{3}$ had a variety of meanings in the Caroline period: "great mental acumen, cleverness, wisdom, quickness of intellect or liveliness of fancy, capacity of apt expression and talent for saying brilliant or sparkling things."

Brome seems to use what Martin Butler (1984:159) calls the Middletonian brand of wit consisting in the characters' "capacity to swindle," that is achieving social recognition, even trampling on feelings and moral values, and taking advantage of other people. This increasing dominance of the economic motive in every sphere of human life thus implies that the power of money can buy everything: love, sex, friendship and respect. As the courtier Rufflit states, in a passage which is reminiscent of Timon of Athens, cheating other people in order to gain money is not only legitimate, but also natural:

Conscience! All things rob one another: churches poll the people; princes pill the church; minions draw from princes; mistresses suck minions; and the pox undoes mistresses; physicians plague

\footnotetext{
${ }^{1}$ Elizabeth Schafer emphasizes that the titles of numerous works of the period contain the word 'wit'. She mentions Wit at Several Weapons; Brome's own lost play Wit in a Madness; Middleton's No Wit No Help Like a Woman's, Glapthorne's Wit in a Constable; Shirley's The Witty Fair One; Fletcher's Wit Without Money. I add Davenant's The Wits (1636) and Greene's Groats-Worth of Wit, which is considered among the main sources of the play.

${ }^{2}$ In the prologue, Sarpego claims to be "the city wit" of the title ("I, that bear its title"), Pyannet tells Crasy "note my wit" (III, 2, speech 429), to cite just a few of the numerous examples.

${ }^{3}$ Interestingly, as for the word "wit", the OED quotes Brome twice, for The Court Beggar and The Northern Lass, without mentioning The City Wit where the word is repeated extremely often.
} 
their patients; orators their clients; courtiers their suitors, and the Devil all. The water robs the earth; earth chokes the water; fire burns air; air still consumes the fire.

Since elements themselves do rob each other,

And Phoebe for her light doth rob her brother,

What is't in man, one man to rob another? (IV, 1 , speech 620$)^{4}$

Actually, The City Wit is the first dramatic descendant of Timon of Athens and what Lucullus says about Timon is also valid for Crasy, the protagonist of the play: "Every man has his fault, and honesty is his" (III, 1, 29-30). The bankrupt jeweller Crasy, akin to Timon, is "a formerly generous but now penurious hero who is confronted with ingratitude and employs a variety of intrigues" (Knight 1967:211) and disguises in order to regain what he has lost, after being defrauded by his creditors who refuse to pay him back. Richard Cave (2003:88) comments that Crasy's "generosity lays him open to cynical manipulation by the people he thinks he is helping. He recovers his lost fortune only by being a 'wit', that is by robbing his former "friends"', his family, his wife Josina, the courtiers, the pedant Sarpego and the draper Linsy-Wolsey. The jeweller succeeds also thanks to his apprentice Jeremy, disguised as widow Tryman, and the servant boy Crack, with whom he revives the Jonsonian triumvirate of Subtle, Doll and Face in The Alchemist: ${ }^{5}$

Then let us be friends and most friendly agree.

The pimp and the punk and the doctor are three,

That cannot but thrive when united they be.

The pimp brings in custom, the punk she gets treasure,

Of which the physician is sure of his measure,

For work that she makes him in sale of her pleasure.

For which, when she fails by diseases or pain,

The doctor new vamps and upsets her again. (III, I, speech 396)

\section{Social dynamics}

In the seventeenth century, English society, far from being an immutable caste system, is characterized by a marked social mobility owing to massive migration towards the city and the new forms of

\footnotetext{
${ }^{4}$ All the quotations from the play are from Schafer's edition (2010).

${ }^{5}$ As for the connections with The Alchemist see also Andrews (1972 (1913):85), Clark (1992:172) and Schafer (2010:n9755).
} 
individual acquisition (such as the purchase of titles or lands). Since rank is determined also according to the possession of money, the idea of advancement involves all the classes in a constant longing for power: "the countryman's eye is upon the citizen; the citizen's is upon the gentleman; the gentleman's is upon the nobleman" (Knights 1951:108). In The City Wit Brome clearly mirrors this order of society emphasizing the various manifestations of social interaction conceived in terms of do ut des: all the relationships are based on the idea of exchange so that people become thus both consumers and consumed (Newman 1989:506), subjects and objects of economic transactions.

The playwright dramatizes the social dynamics in its two dimensions: on the one hand, on the horizontal axis, he puts on stage a set of characters who wish to consolidate their position in their own class; on the other, according to the vertical lines of hierarchy, he presents both the traditionally established positions of dominance or subordination assigned by status and gender and the continuous rise of social climbers who play a decisive role in the dynamic courtcity.

\section{Spatial interaction}

The ever-growing tensions between the court and the city have become embedded in urban topography so that the London setting of the play clearly reflects the opposition between these two poles of the interaction in the citizen-courtier dynamic: the mercantile world (represented by the houses of the jeweller Crasy and the draper Linsy-Wolsey) and the court (the Presence Chamber and Sir Andrew Ticket's house).

The chart summarizes the interaction of the characters among themselves and the different places, pointing out not only the relevance of any single character but also how gender and class limits regulate the admittance to a place. The restricted number of people in the court scenes (six characters in the Presence scene and at Sir Andrew Ticket's house) reflects the hierarchical-elitist principles governing a space whose access depends on rank or on invitation. On the contrary, all the characters are granted free access to the urban space so that the scenes within the citizen milieu are much more crowded. 


\begin{tabular}{|c|c|c|c|c|c|c|c|c|c|c|c|c|c|c|}
\hline & \multicolumn{2}{|c|}{ THE COURT } & \multicolumn{12}{|c|}{ THE CITY } \\
\hline & \multirow{2}{*}{$\begin{array}{c}\begin{array}{c}\text { The Presence } \\
\text { Chamber }\end{array} \\
\text { III, } 4\end{array}$} & \multirow{2}{*}{$\begin{array}{c}\begin{array}{c}\text { Sir Ticket's } \\
\text { House }\end{array} \\
\text { IV, } 2\end{array}$} & \multicolumn{9}{|c|}{ Crasy's house } & \multicolumn{3}{|c|}{$\begin{array}{c}\text { Linsy-Wolsey's } \\
\text { house }\end{array}$} \\
\hline & & & $\mathrm{I}, \mathbf{1}$ & $\mathrm{I}, 2$ & II,1 & II,2 & $\mathrm{II}, 3$ & III, 2 & $\mathrm{IV}, 1$ & $\mathrm{IV}, 3$ & $\mathrm{v}, 1$ & III,1 & III, 3 & IV, 4 \\
\hline \multicolumn{15}{|l|}{ CITIZENS } \\
\hline $\begin{array}{ll}\text { Crasy } & \text { (11) }\end{array}$ & $x$ & & $\mathrm{x}$ & $\mathrm{x}$ & $x$ & $\mathrm{x}$ & & $x$ & $x$ & $\mathrm{x}$ & $\mathrm{x}$ & $x$ & $x$ & \\
\hline $\begin{array}{l}\text { Sarpego }(9) \\
\end{array}$ & $\mathrm{x}$ & $\mathrm{x}$ & $\mathrm{x}$ & $\mathrm{x}$ & $\mathrm{x}$ & & & $x$ & $\mathrm{x}$ & & $\mathrm{x}$ & $\mathrm{x}$ & & \\
\hline $\begin{array}{ll}\text { Josina } & \text { (7) }\end{array}$ & & & $\mathrm{x}$ & $\mathrm{x}$ & & $\mathrm{x}$ & & & $\mathrm{x}$ & $\mathrm{x}$ & $\mathrm{x}$ & $\mathrm{x}$ & & \\
\hline $\begin{array}{ll}\text { Pyannet } & (6)\end{array}$ & & $\mathrm{x}$ & $\mathrm{x}$ & & & & & $\mathrm{x}$ & $\mathrm{x}$ & & $\mathrm{x}$ & $x$ & & \\
\hline Linsy-Wolsey (6) & & & & $\mathrm{x}$ & & & $\mathrm{x}$ & & & & $\mathrm{x}$ & $\mathrm{x}$ & $\mathrm{x}$ & $\mathrm{x}$ \\
\hline Mr. Sneakup (5) & $\mathrm{x}$ & $\mathrm{x}$ & $\mathrm{x}$ & & & & & $\mathrm{x}$ & & & $x$ & & & \\
\hline \multicolumn{15}{|l|}{ COURTIERS } \\
\hline \begin{tabular}{ll|} 
Rufflit & $(8)$
\end{tabular} & $\mathrm{x}$ & $\mathrm{x}$ & $x$ & $x$ & . & & $x$ & & $\mathrm{x}$ & & $x$ & $\mathrm{x}$ & & \\
\hline Toby & $x$ & $\mathrm{x}$ & $\mathrm{x}$ & $\mathrm{x}$ & $\mathrm{x}$ & & $\mathrm{x}$ & & & & $\mathrm{x}$ & $\mathrm{x}$ & & \\
\hline Lady Ticket (3) & & $\mathrm{x}$ & $x$ & & & & & & & & $x$ & & & \\
\hline $\begin{array}{ll}\text { Sir Ticket } & (7)\end{array}$ & $\mathrm{x}$ & & $\mathrm{x}$ & $\mathrm{x}$ & & & $\mathrm{x}$ & & $\mathrm{x}$ & & $x$ & $\mathrm{x}$ & & \\
\hline \multicolumn{15}{|l|}{ LOWER CLASS } \\
\hline $\begin{array}{ll}\text { Jeremy } & (3+2)\end{array}$ & & & $\mathrm{x}$ & $\mathrm{x}$ & & & & & & & $\mathrm{x}$ & & & \\
\hline $\begin{array}{ll}\text { Tryman } & (3+2)\end{array}$ & & & & & & & & & & & $\mathrm{x}$ & $\mathrm{x}$ & $\mathrm{x}$ & \\
\hline \begin{tabular}{ll|} 
Crack & $(7)$
\end{tabular} & & & & & & $\mathrm{x}$ & $\mathrm{x}$ & & $x$ & & $\mathrm{x}$ & $x$ & $\mathrm{x}$ & $\mathrm{x}$ \\
\hline Bridget & & & $x$ & & & $\mathrm{x}$ & & $x$ & $\mathrm{x}$ & & $\mathrm{x}$ & & & \\
\hline Isabell (1) & & & & & & & & & & & & $\mathrm{x}$ & & \\
\hline Jone (1) & & & & & & & & & & & & $\mathrm{x}$ & & \\
\hline
\end{tabular}

Kim Durban ${ }^{6}$ (2010:14), who directed a production of The City Wit in 2007 in Australia, affirms that "Richard Brome [...] is not afraid to fill the stage with many characters, and wittily play them off against each other, using asides frequently to release the dramatic pressure. [...] The challenge is to stage the group-takeover as mob action, whilst keeping their individual contributions crisp." At the beginning of the play, at Crasy's home, the jeweller confronts all his debtors in front of his family and servants (eleven out of sixteen characters are mentioned). Discussing the confrontation, Durban (2010:16) describes it as "an artfully composed scene that is fiendishly difficult to stage. It uses a device that Brome repeats throughout the play - the scene starts with intimacy, swells to accommodate a crowd and ends with just one character, Crasy's wife, Josina. This scenic structure, requiring the stage to fill and empty with a flow and ebbing of characters, continues throughout the play." This happens also later, in III, 1 when courtiers and citizens rush to widow Tryman's bedside at Linsy-Wolsey's house (twelve characters). Finally, the city becomes the space where the

\footnotetext{
${ }^{6}$ Kim Durban staged The City Wit in Ballarat, Australia, with a company of graduating acting students. In order to delight her audience and emphasize the connections between the city comedy and contemporary times, she chose to set the play in the 1970s. I make reference to this and other productions of the play in order to clarify significant theatrical aspects of the performance.
} 
dénouement in act $\mathrm{V}$ can take place in front of fourteen characters. Beside the main character Crasy, whose presence is due both to the plot and to his capacity for disguise, only Sarpego is on stage almost as assiduously as him. Moreover, the pedant and Toby are the sole characters who attend all four settings: as social climbers, they embody the idea of vertical mobility, since they know their way around the different social milieu and are adaptable to the places as far as their behaviour, attitude and language are concerned. Obviously, the courtiers' higher status allows them to attend most of the setting and to take part in the key moments of the play, such as the scene in the Presence Chamber and the reading of Tryman's will in III, 1. By contrast, the interaction of some characters is reduced to the milieu they belong to because of social restrictions: beside the servants Isabell and Jone, whose role is circumscribed, Crack and Bridget are similarly prevented from any kind of social advancement. Crack's fear of prison casts him in a marginal role, whereas Bridget's single attempt at a social rise is frustrated by Sarpego who breaks his promise to marry her. Thus, the two servants can only strengthen their position in the lower class through their own marriage. Class and gender boundaries limit Jeremy as well. He is neglected by the courtier world as a male servant, yet awakens interest as the attractively rich Tryman. Nevertheless, the widow's interaction with the courtiers only occurs when they enter her citizen space, since she is neither invited nor allowed to go to court.

Among the women, the most relevant role is played by Josina, who is involved in seven scenes in two citizen settings. Her interaction is limited to her own social milieu as she is not allowed to leave the citizen sphere owing to gender restrictions and her downscale marriage with the struggling tradesman Crasy. Gender restrictions are less effective for Lady Ticket and Pyannet. Enjoying more freedom thanks to her husband's courtly status, the former can take part in the scenes within the citizen sphere. The latter, on the contrary, by mastering the space and its rules, dares to invade a place which is above her socially (in fact she goes to Ticket's house to punish her husband for his presumed infidelity) claiming her hegemonic role within her family unit. 


\section{The geography of the play}

Besides the spatial opposition between court and city, space is given prominence through the numerous references to real places known or habitually frequented by the characters. Elizabeth Schafer (2010:intro \$9) argues that "Brome may throw in a few real place names but he does not worry about creating much of a sense of London. [...] Apart from Josina's speech in 1.1 [CW 1.1 speech 91], which is working to characterize Josina rather than evoke the city, there are only a couple of standard references to Bridewell, Clerkenwell etc. and nothing like the sense of a location that permeates, for example, Covent Garden Weeded." On the contrary, like Darryl Grantley (2008:160-161), I am inclined to believe that in the play "the City is strongly realized in allusions." All the hints at places, besides those mentioned by Josina in Act I, 1 , show the different functions of space in relation to the identity of the single character within the social system or of a group. I identify three principal functions: firstly, a main function in which the topography of the place concurs to reflect the personality of the character; secondly, an evocative one when it conveys a further meaning independently from the geographical position of the place; finally, when space contributes to shape a new identity.

The first function tends to emphasize the relationship between identity and the place within the milieu as far as its position, history and social use are concerned. Josina's references to space both evoke a female microcosm, and allude to some traits of her personality. As soon as Crasy leaves, his wife Josina starts a quest for a lover and sends her maid Bridget to contact some friends of hers in places in the Old City, the commercial part of London:

Go your ways to Mistress Parmisan, the cheesemonger's wife in Old Fish Street, and commend me to her and entreat her to pray Mistress Cauliflower, the herb-woman in the Old Change, that she will desire Mistress Piccadell in Bow Lane in any hand to beseech the good old dry- nurse mother. (I, 1, speech 91)

Her allusions to the citizen space demonstrate her membership of the middle class, and seem to prove the existence of a widespread trade, a sort of sub-economy, among women, whose names refer to their professions, like Mistress Parmisan or Mistress Cauliflower. This may indicate the changing place of women of this class, like widows of merchants who reach new positions of economic power 
or workers in their husbands' shops who are, de facto, full partners in the family business, though not holding "official" positions.

The names of the places also hint at the issues traditionally associated with women, such as shopping, fashion and sex. Bridget has to look for the herb-woman in the Old Change, ${ }^{7}$ where drapers' shops were located in Brome's times. Then, the quest stops at Bow Lane $^{8}$ which is accessed from the port of Queenhithe. Since this is a popular shopping street, the name of the woman, mistress Piccadell, appears to be strictly connected with the idea of trade and fashion, as a piccadill was a decorative edging of cut work or vandyking, especially on a collar, sleeve, or ruff $(O E D, \mathrm{n} .1)$. Cheapside, ${ }^{9}$ the market par excellence, is later evoked ironically as the place where Linsy-Wolsey is said to be going shopping to buy some fabric for the widow: "Among the mercers so troubled, as if all the satin in Cheapside were not enough" (III, 3, speech 460). The most relevant reference in my view is to Old Fish Street, called after a fish market operating since the Middle Ages. Its name is an example of the London habit of naming streets after craftsmen or the produce that used to be sold there. The same can be said of streets like Honey Lane, Leather Lane, Beer Lane, Shoe Lane or Butcher Row. What is relevant is that Josina's search for a lover starts in a place with strong sexual implications of the connections between fishmongers and

7 Old Change, also known as the Old Exchange after 1566, when the new Royal Exchange was opened, was a street in London running south from the west end of Cheapside to Knightrider Street. It was named after the King's Exchange for bullion and for the changing of foreign coins. It occurs also in Dekker's The Shoemaker's Holiday (III, 3, 51), when Hammonds says: "there is a wench keepes shop in the Old Change." See Stow (1908 (1598): I.54, 312-313, 323) and Chandler (1929:500).

${ }^{8}$ Bow Lane runs north-south between Cheapside and Old Fish Street in the ward of Cordwainer Street. It owes its name to the church of St. Mary-le-Bow which was built on the south-west corner of Bow Lane and Cheapside and was originally called St. Mary de Arcubus, then before being renamed St. Mary-le-Bow by about 1270. This is the description of Bow Lane given by the 16th century historian John Stow (1908 (1598): I.81): "[T]his street beginneth by West Cheape, and Saint Marie Bow church is the head thereof on the west side, and it runneth downe south through that part which of later time was called Hosier Lane, now Bow Lane, and then by the west end of Aldmary Church, to the new builded houses, in place of Ormond house."

\footnotetext{
${ }^{9}$ In Medieval times it was known as 'Westcheap' to distinguish it from Eastcheap. It was open at dawn in winter and at six o'clock in summer and for half an hour before the close there was the ringing of a bell to warn the shoppers. From the Tudor Period, movable stalls were gradually replaced by permanent shops with houses above them, inhabited by rich merchants. See Hibbert (1969:36).
} 
prostitution, as in Hamlet ("Excellent well. You are a fishmonger," II, 2 , 174). Her reference thus could suggest the idea of a free moral conduct and the habit of attending this kind of place. A similar conjecture is made by Crasy: "Well Dol, that thou saist is thy name though I had forgotten thee, I protest. About London-wall was it (saist thou?). Well, I cannot but highly commend thy wisdom in this, that so well hast mended thy election" (III, 3, speech 456). When Tryman declares to have met Crasy before at the London Wall, ${ }^{10}$ she alludes to an illicit sexual relationship with him. Despite admitting that he must have had sex with Tryman, the jeweller does not remember anything about it, which implies that he was used to having sex with prostitutes and that he had too many sexual partners to remember all of them in detail. When the audience realizes that Tryman actually is Jeremy in disguise, this episode becomes much funnier in retrospect. Place reflects the psychological identity of a character also in the case of Crack, Jeremy's brother: most of the references connected to Crack hint at crime or at lowerclass places. Firstly, Crack is introduced as "one of the true blue boys of the hospital" (III, 1, speech 391). In fact, blue was a colour commonly used by servants, tradesmen and boys attending charity school, in this context, probably the Charterhouse school near Clerkenwell, where Tryman claims to be from. Secondly, Crack is threatened to be sent to Bridewell, ${ }^{11}$ and every time the prison is mentioned it is always in regard to him. Interestingly, the name Bridewell originally refers to Saint Bridget (Bride is a form of Bridget) and the well near there, as if Crack's obsession for that place were personified by his love Bridget, Josina's chambermaid. Later, his preoccupation with prisons re-emerges while he is talking to Crasy: "Crasy: Thou art a brave lad, and in the high way of

\footnotetext{
${ }^{10}$ This was once London's main rubbish disposal site. Its name, according to the 16th century historian John Stow, was derived "from that in old time, when the same lay open, much filth (conveyed forth of the City) especially dead dogges were there laid or cast."

${ }^{11}$ Bridewell was situated between St. Paul's and The Temple and it was once a Norman fortified palace; the kings as well as the court were lodged there till as late as Henry IX. It was rebuilt in 1522 by Henry VIII as a beautiful house purposely for the entertainment and the accommodation of the Emperor Charles V when he came to London. In 1553 it was given by Edward VI to be a workhouse for the poor and idle people of the city and he wanted it to be called the king's hospital or house of correction. Then, it became a prison for vagabonds and prostitutes. See Hibbert (1969:44).
} 
preferment. Crack: Not the high Holborn way, I hope Sir" (III, 1, speeches 397-398). His sense of guilt makes him misinterpret Crasy's praise so that the only possible highway for him is Holborn Way, the road prisoners used to take from Newgate to their execution at Tyburn Tree.

Another function of place reference is evocative, when the citation conveys a further meaning independently from use and geographic collocation of the place. Before the wedding between Tryman and Toby, Crack sings an hymeneal song much to the shock of all those present:

CRACK: Was wont to be still the old song

At high nuptial feasts

Where the merry, merry guests

With joy and good wishes did throng.

But to this new wedding new notes do I bring,

To rail at thee Hymen while sadly I sing.

Fie o Hymen, fie o Hymen, fie o Hymen,

What hands, and what hearts dost thou knit?

A widow that's poor,

And a very, very whore,

To an heir that wants nothing but wit.

Yet thus far, O Hymen, thy answer is made:

When his means are spent, they may live by her trade. $(\mathrm{V}, 1$, speech 914)

The song is justified by Linsy Wolsey as "a song [...] made by a couple that were lately married in Crooked Lane" (V, 1 , speech 916). ${ }^{12}$ The reference to this existing place near Eastcheap on the one hand reinforces the suitability of this song for such an occasion, but on the other it conveys a double meaning, as "crooked" evokes dishonesty and tricks which cast a shadow on their marriage.

Finally, space can be used by the characters to reshape a personality, like Tryman, who builds up a new identity and a past life through the references to real places and their cultural elements. The character seems to have a multiple identity since Jeremy plays the part of the prostitute Tryman disguised as a wealthy young widow. As a widow, she becomes immediately the target of some fortune hunters, a financial and sexual prey, hunted for her money.

12 "At the upper end of new fishstreete is a lane turning towards S. Michael lane, and is called Crooked lane, of the croked windings thereof." See Stow (1908 (1598): I.216). 
Only Crasy knows that she is actually a prostitute since they are in league:

TRYMAN: Are they all gone? Now Master Doctor, what think you of the sick widow? Has she done her part hitherto?

CRASY: Beyond my expectation! Better than I for a doctor.

TRYMAN: You are right. And I am even the same for a widow as you for a doctor. Do not I know you? Yes good Master Crasy. I dare trust you, because you must trust me. Therefore know, that I, the rich widow, am no better than a lady that must live by what I bear about me. The vulgar translation you know, but let them speak their pleasure; I have no lands and, since I am born, must be kept. I may make the best of my own, and if one member maintain the whole body, what's that to anyone? (III, 1, speeches 385-387)

Crack claims that Tryman the prostitute is from Clerkenwell, a northern district of London, home of the Charterhouse where Brome spent his last years. The place reifies the two opposing aspects of the character: the respectable image of the widow, represented by the fashionable houses, and the dishonorable one of the prostitute by the brothels and the prisons. Clerkenwell, which took its name from the Clerks' Well in Farringdon Lane, was known as an elegant residential area:

In 1620 Clerkenwell had been a fashionable country village, despite the smell of the brewery and the noise of the forge in St John Street which, so the Earl of Exeter complained, made his dining room uninhabitable. Aristocrats and rich City magnates, who travelled by coach to their counting-houses each day, both lived there in pleasant harmony. As the century progressed, [...] Clerkenwell's aristocratic residents, including at one time the Earls of Essex, Carlisle and Ailesbury, abandoned its now displeasing atmosphere for more attractive places to the west. Also, there was a feeling amongst the well-born that it was somehow degrading to live too close to tradesmen, however rich. (Hibbert 1969:61)

Nevertheless, the area had also a well established reputation for burglary and was a notorious centre of prostitution; it was the site of Clerkenwell Bridewell, a prison built in 1616 as an overflow for Bridewell; later in the century, a new prison was built there to relieve Newgate. Posing as a sick, wealthy Cornish widow, Tryman manages to convince the courtiers and to a greater extent the citizens 
during the reading of her will: "I, Jane Tryman of Knockers Hole, in the County of Cornwall, widow, sick in body, but whole in mind, and of perfect memory, do make my last will and testament, in manner and form following" (III, 1, speech 368). Knockers Hole is a real place in Cornwall, at St. Germans near Plymouth but, besides the geographical relevance, the name provides a pun: among the possible meanings of knockers there is "person of striking appearance" (OED 1.c), whereas a common usage of hole was "orifice," often in the vulgar sense of genital organs. Combining the genitive form of the former and orifice, the joke is quite evident. Tryman thus is from a place meaning orifice of an attractive person (Schafer 2010:n7390). All the details about the legacies to her assumed family members concur to give consistency to her character since the names of her heirs are coherent with her Cornish origin: many Cornish surnames and names of places have the prefixes "tre", "pol-" or "pen-", as the old saying quoted by Tilley (T479) testifies: "By Tre, Pol and Pen you shall ye know all Cornishmen."

'Tis forty shillings. Item, to my nephew, Sir Marmaduke Trevaughan of St. Miniver, one thousand pounds in gold. Item to my nephew Master Francis Trepton, one thousand pound in gold. Item, to my kinsman, Sir Stephen Leggleden, I do forgive two thousand pound, for which his lands are mortgaged to me. [...]

Item, to my niece Barnara Tredrite, five hundred pound; my second basin and ewer, a dozen of silver dishes; and four dozen of silver spoons. (III, 1 , speeches 375,378 )

Actually, one of Tryman's nephews is called Sir Marmaduke Trevaughan of St. Miniver (a coastal town in north Cornwall); another one is Master Francis Trepton; the niece is Barbara Tredrite. According to Schafer (2010:n7406), "tread" could also suggest a joke as the word is used for the copulation of birds (OED, v.8. a, b). Later, the same pun recurs in Pyannet's words: "How now Madam Tiffany! Will none but my cock serve to tread you? Give me my jewels, thou harlot!" (IV, 2, speech 672). Therefore, the name combines the idea of the character's Cornish origin and a sexual connotation which is appropriate to Tryman as a prostitute. 


\section{The presence scene: an example of spatial interaction}

In the play the contemporary English Court is given great prominence and, although there is no mention of the name of the palace involved or of "the royal person whose messenger Crasy pretends to be, it none the less strongly implies that the palace is Whitehall and the royal is Charles" (Steggle 2004:28). The picture of life at court allows Brome to show the strict protocol while mocking royal ritual as well as those who perform it. He also provides a vivid picture of the courtly world through its inhabitants, staging the contrast between new and old nobility and the different types of courtiers: the bachelor, the married male and the female courtier. Rufflit, the bachelor, exemplifies the perfect courtier:

a thing that but once in three months has money in his purse; a creature made up of promise and protestation; a thing that fouls other men's napkins: touseth other men's sheets; flatters all he fears; contemns all he needs not, starves all that serve him, and undoes all that trust him. (I, 2, speech 114)

Interestingly, despite being excluded from the Court, Pyannet shows thorough knowledge of Whitehall, of its etiquette and of the royal ritual. At that time, the palace was the largest royal palace in Europe containing some 2,000 rooms and covering twenty-three acres compared with Versailles' seven and a half, the Escorial's eight and a half, and Hampton Court's modest six (Thurley, 1998:4). Its topographic description is given by Pyannet, while teaching her husband how to master that alien environment space and how to behave. Before reaching the Presence Chamber, Mr. Sneakup has to pass through a succession of outer rooms since "the protocols of speech in the early modern court were made visible as protocols of space" (Smith 2004:103).

PYANNET: Now mark. I will instruct you: when you come at the Court Gate, you may neither knock nor piss. Do you mark? You go through the Hall covered; through the Great Chamber covered; through the Presence bare; through the Lobby covered; through the Privy Chamber bare; through the Privy Lobby covered; to the Prince bare.

SNEAKUP: I'll do't, I warrant you. Let me see. At the Court Gate neither knock nor make water. May not a man break wind? 
PyANNET: Umh. Yes, but (like the Exchequer payment) ${ }^{13}$ somewhat abated. (III, 2, speeches 435-437)

John Astington (1999:38) underlines the accuracy in Pyannet's description, though her instructions outline a fantastical version of a visit to Whitehall since the place was not accessible to a character like Sneakup in real life, owing to the strict rules and rigid measures of security which protected the monarch. Inside Whitehall there were four sorts of spaces: courts, galleries, large ceremonial chambers, and smaller rooms, each having its own social functions. The rooms "progressed from larger, more public space to smaller, private, and increasingly secure and inaccessible chambers." The Great Chamber, or Guard Chamber, was the first and largest room; the following chamber "was occupied partly by members of the royal guard, armed, and dressed in a fashion similar to their modern descendants, the Yeoman of the Guard" in order to mark "the boundary of a restricted and privileged area" and beyond this lay the Presence. Finally, the royal private apartments with the Privy Lobby, which was a private passage used as an ante-room and the Privy Chamber. In the following sequence, Pyannet pretends to be the King in a sort of rehearsal of Sneakup's visit to the palace. As in a play-within-a-play, she makes him play his part, the jeweller Crasy, with particular attention to words, movements and gestures. This enables Brome to create a parody of the increasing codification and ritualisation of the court etiquette. Actually the King "tried to make the court a microcosm of the kingdoms to be - an ordered and virtuous commonwealth under his paternal rule" (Young 1997:81). A fine example of this strict code of behaviour is the reference to the use of triple bowing at mealtimes introduced by Charles I ("my three legs" III, 1, speech 444). ${ }^{14}$

PYANNET: Suppose me the Prince. Come in, and present. Here sits the Prince. There enters the jeweller. Make your honours. Let me see you do it handsomely.

SNEAKUP: Yes, now I come in, make my three legs... and then...

PYANNET: Kneel.

SNEAKUP: Yes, and say...

\footnotetext{
${ }^{13}$ Steggle (2004:29) takes this reference as a "sly remark about Charles's budgetary difficulties in the Exchequer in the years after 1628."

${ }^{14}$ See Steggle (2004:30).
} 
PYANNET: What?

SNEAKUP: Nay, that I know not.

PYANNET: [As CRASY]. An't please your Grace, I have certain jewels to present to your liking.

SNEAKUP: [As CRASY]. An't please your Grace, I have certain jewels to present to your liking.

PyANNET: [As the Prince]. Is this Crasy, that had wont to serve me with jewels? [As Holywater]. It is that honest man, so please your Highness. [As PYANNET] (That's for Master Holywater, the byflatterer, to speak.) [As the Prince]. You are a cuckoldly knave, sirrah, and have often abused me with false and deceitful stones.

SNEAKUP: [As CRASY]. My stones are right $^{15}$, so please your Excellence. (III, speeches 443-452)

It is difficult for a modern audience to realize how audacious staging the Presence Chamber ${ }^{16}$ "was as well as letting"a woman ${ }^{17}$ take the role of the King in a play where the sovereign is nearly put on stage, and to do so precisely in the Presence Chamber where the "throne represented the majesty of the monarch even in his absence" (Sharpe 1996:213). Moreover, as Wilkinson (2004:introduction) remarks, "a woman who pretends to be the monarch encourages comparisons with the king that suggest something about his masculinity, particularly as he is being portrayed by a shrewish woman whose own gender identity is an issue of the play. There are

\footnotetext{
${ }^{15}$ According to Elizabeth Schafer (2010:n7514) the expression "my stones are right" can have two meanings: "the jewels that I am selling are good ones" and "my testicles are functioning, I am able to father children", thus increasing the sexual overtones of the scenes at court.

${ }^{16}$ Actually, in a production of The City Wit at Royal Holloway, University of London in 2007, anything to do with the Presence was cut "as the jokes here were considered something a contemporary student audience would not be able to access" (Schafer 2010:intro \$52). By contrast, in the Australian version it was turned into "a club indicated by the silken ropes needed to control a crowd. An orange sculpture, vaguely phallic in shape, was wheeled from place to place, used by various characters to hide behind, and in the denouement, hid Crasy himself behind a secret door" (Durban 2010:13).

${ }^{17}$ It is worth considering that in the production of The City Wit at Royal Holloway, Pyannet was dressed as Margaret Thatcher. Moreover, Michael Billington (Guardian. 20 February 1992), reviewing the 1991 RADA performance of the play directed by Gordon McDougall, claimed that "The City Wit was treated 'as the Serious Money of its day', making a comparison with Caryl Churchill's Serious Money. A City Comedy (1987), a play about the stock market in England in the 1980s while Margaret Thatcher was Prime Minister.
} 
other references made in the play that could be read as being derogatory about Charles and his appearance."

The scene in the Presence Chamber is particularly significant as the way each character interacts with the space clearly reflects his social status. Six of the characters are involved in this scene, Sarpego, Crasy, Mr. Sneakup, Toby, Rufflit and Sir Andrew Ticket, who are part of complex dynamics of interaction. The scene is opened and closed by Sarpego who believes he has been invited to court by his pupil Toby. Only by saying "This is the Presence," he creates the atmosphere of the court so that the audience has the impression of being inside the Chamber with him.

This is the Presence. I am much amazed, or stupefied, that Master Tobias Sneakup, my quondam pupil, attends not my conduct! Ha! So instant was his Grace, his importunity to enjoy me, that although I purchased the loan of clothes, yet I had not vacation, nor indeed variety, to shift my shirt. (III, 4 speech 481 )

His interaction with the place involves also the appropriate apparel: Sarpego enters in gorgeous clothes $^{18}$ in order to try to compensate for the lack of nobility with clothing and language: "to appear the more perfect courtier at the first dash, I will say that though my outside were glorious, yet of purpose I left my inside lousy" (III, 4, speech 483). In fact, he is wearing a dirty undershirt suggesting that appearance can be deceptive and there is something rotten at the core of the court. Once he gets in, he immediately recognizes Mr. Sneakup who has to impersonate Crasy and is dressed like a citizen. Even before entering the palace, he feels awkward, out of place, jeopardizing a profitable interaction with a place he is frightened of. After a while, Crasy, in disguise as a royal messenger, comes in pretending to be looking for Mr. Crasy and his jewels. The stage direction "Crasy at the hangings" ("hangings" is "an infrequently used alternative for the curtain or arras that hung just in front of the tiring house wall" (Dessen and Thompson 1999:110) actually suggests Crasy's attempt to conceal himself and the possibility of spying on other people without being noticed. He dominates the space since he knows where he can hide himself, whereas all his fellow townsmen are venturing into an unknown

${ }^{18}$ For Durban (2010:14) "Enter Sarpego in gorgeous apparel" was "a delicious invitation to a costume designer." She collaborated with the designer John Bennett who made richly allusive costumes like Pyannet's who was dressed as a Versace diva. 
place. As a consequence, when the stage direction reads "Enter Crasy in haste," the character has been on stage for a long time, unnoticed by the other characters. This creates a comic situation since the audience is aware that the real jeweller is on stage, though in disguise.

With his convincing disguise as a court messenger, Crasy is able to cheat Sneakup into giving him the jewels ("You know me; give me the jewels. [...] But betwixt us both we'll make a shift to cheat him. Stay you here. I will return instantly": III, 4, speech 403) and Sarpego at the same time ("O Mr. Sarpego! Your pupil will come and conduct you presently" III, 4, speech 496). Obviously, Crasy avoids meeting both the courtiers and Toby, who stay in their own territory and have more detailed knowledge of the place. As soon as the courtiers arrive, the fraud against Sneakup and Sarpego is unveiled, and they both have to leave the Chamber. By virtue of his status, Mr. Sneakup finds refuge at court in Lady Ticket's chamber in order to elude his wife's anger after the loss of the jewels:

TOBY: Father, heaven pardon me, for sure I have a great desire to call you cockscomb. I sent no man, nor is there any so styled as Holywater about the Court. [...]

SNEAKUP: Son, I am not so very a fool, but I perceive I am made a stark ass. O son, thy father is cozened, and thy mother will beat me indeed unless your charity conceal me in the Court here, till her fury be over.

TICKET: He shall stay at my wife's chamber. (III, 4, speeches 513518)

Instead, when Sarpego realizes that he has not been invited, he is driven out of the Presence Chamber since his own presence is now unwarranted: "Sic transit gloria mundi. The learned is cony-caught and the lover of Helicon is laughed at. The last six-pence of my fortune is spent and I will go cry in private" (III, 4, speech 523).

In The City Wit, Brome gives a cross-section of the urban London geography as well as an honest and precise portrait of English society, where people are subject to appearances and conventions as if they had a script and a part to play in the performance of everyday life, as if "everyone in London wore a costume" (Ackroyd 2009:150) adaptable to suit to any occasion. The play contributes to the representation of the changing shapes of social life and of the social identity of the inhabitants during the 
reign of Charles I, a turbulent period of the English history, in which the playwright recognized the early symptoms of the crisis which would lead in a few years to the Civil War and to the fall of the monarchy. The City Wit mirrors the demands that the monarch was failing to satisfy through the use as a setting of the Presence Chamber, the most powerful and evident symbol of power in London and of the sovereign. Brome's potentially subversive choice deprives the court of a degree of political and legislative importance and seems to suggest that the only laws in force in London are empty royal protocols.

\section{References}

Ackroyd, Peter 2009. London: The Biography. London: Chatto and Windus.

Andrews, Clarence E. 1972 (1913). Richard Brome: A Study of His Life and Works. New York: Archon.

Astington, John 1999. English Court Theatre: 1558-1647. Cambridge: Cambridge University Press.

Brome, Richard 2004 (1629-1632). The City Wit. Ed. Katherine Wilkinson <url: http://extra.shu.ac.uk/emls/iemls/renplays/citywit.htm>. Last accessed 20/10/2010.

Brome, Richard 2010 (1629-1632). The City Wit, Modern Text. Ed. Elizabeth Schafer. Richard Brome Online <url: http://www.hrionline.ac.uk/brome ISBN 978-0-9557876-1-4>. Last accessed 20/10/2010

Butler, Martin 1984. Theatre and Crisis, 1632-1642. Cambridge: Cambridge University Press.

Chandler, W. K. 1929. “The Topography of Dekker's The Shoemaker's Holiday." Studies in Philology 26/4: 499-504.

Cave, Richard Allen 2003. "The Playwriting Sons of Ben: Nathan Field and Richard Brome." Ed. Brian Woolland. Jonsonians: Living Traditions. Aldershot: Ashgate. 69-91.

Cave, Richard Allen 2008. "Endings in Renaissance Comedy: Ben Jonson and Richard Brome." Ed. Daniela Carpi. Practising Equity, Addressing Law: Equity in Law and Literature. Heidelberg: Winter. 263-283.

Clark, Ira 1992. Professional Playwrights. Massinger, Ford, Shirley, \& Brome. Lexington: The University Press of Kentucky.

Cressy, David 1980. Literacy and the Social Order: Reading and Writing in Tudor and Stuart England. Cambridge: Cambridge University Press. 
Dessen, Alan C., Thomson, Leslie 1999. A Dictionary of Stage Directions in English Drama, 1580-1642. Cambridge: Cambridge University Press.

Durban, Kim 2010. "Upside down at the bottom of the world: taking Richard Brome to the Antipodes." Richard Brome Online <url: http://www.hrionline.ac.uk/bromeISBN978-0-9557876-1-4>. Last accessed 20/10/2010.

Gibbons, Brian 1980. Jacobean City Comedy. London: Methuen.

Grantley, Darryl 2008. London in Early Modern Drama: Representing the Built Environment. Basingstoke and London: Palgrave.

Hibbert, Christopher 1969. London: The Biography of a City. London: Penguin Books.

Knight, G. Wilson 1967. Shakespeare and Religion: Essays of Forty Years. New York: Routledge.

Knights, Lionel C. 1951 (1937). Drama and Society in the Age of Jonson. London: Chatto and Windus.

Jonson, Ben. 1995 (1616). The Alchemist and Other Plays. Ed. Gordon Campbell. Oxford: Oxford University Press.

Leggatt, Alexander 1973. Citizen Comedy in the Age of Shakespeare. Toronto: University of Toronto Press.

Newman, Karen 1989. "Women and Commodification in Jonson's Epicoene." ELH 56/3: 503-518.

Shakespeare, William 1994 (1606). Timon of Athens. Ed. H. J. Oliver. London, New York: Routledge.

- 2005 (1601). Hamlet. Eds. Richard Andrews and Rex Gibson. Cambridge. Cambridge University Press.

Sharpe, Kevin 1996. The Personal Rule of Charles I. New Haven: Yale University Press.

Shaw, Catherine 1980. Richard Brome. Boston: Twayne.

Smith, Bruce R. 2004. "The Soundscapes of Early Modern England." Ed. Mark M. Smith. Hearing History: A Reader. Athens: University of Georgia Press. 85-111.

Steggle, Matthew 2004. Richard Brome: Place and Politics on the Caroline Stage. Manchester: Manchester University Press.

Stow, John 1908 (1598). A Survey of London. 2 vols. Oxford: Clarendon Press.

Tilley, Morris Palmer 1950. A Dictionary of the Proverbs in England in the Sixteenth and Seventeenth Centuries: A Collection of the Proverbs found in English Literature and the Dictionaries of the Period. Ann Arbour: University of Michigan Press. 
C. Paravano

Thurley, Simon 1998. The Lost Palace of Whitehall. London: RIBA British Architectural Library Drawings Collection.

Wilkinson, Katherine 2005. "A Source for The City Wit." Notes and Queries 52: 230-232.

The Map of Early Modern London. <url: http://mapoflondon.uvic.ca/>. Last accessed 20/10/2010.

How to cite this article:

Paravano, Cristina. "The Space of Identity and the Identity of Space in The City Wit by Richard Brome." SEDERI 21 (2011): 71-90.

Author's contact: aparav@libero.it

Submission: 23/11/2010_Acceptance: 17/2/2011 